\title{
Study and Comparison of the Noise Dose on Workers in a Small Scale Industry in West Bengal, India
}

\author{
Tirtharaj Sen, Pijush Kanti Bhattacharjee, Member,IACSIT, Debamalya Banerjee and Bijan Sarkar
}

\begin{abstract}
This paper refers to a study and effect of Noise Dose in a small scale manufacturing sheet metal industry situated in West Bengal of India. Different noise related data are taken from individual machine and compare with the different noise related variables with $L_{e q}, L_{a v}, L_{A E}$ and TWA (Time weighted average). Noise induced hearing loss (NIHL), which is creating highly environmental pollution, causes the leading occupational disease. For the development of agerelated hearing loss, it creates a major contribution. A noise related hearing loss reduction for workers is proposed in this paper.
\end{abstract}

Index Terms - Precision dosimeter, Small Scale Industry, noise exposure, effect of noise.

\section{INTRODUCTION}

Hearing mechanism damage caused by noise is very much related to the amount of acoustical energy (sound) received by hearing mechanism. The duration of noise exposure level and the susceptibility of the ear are primary factors for noise related hearing loss.

It is important to calculate and control the dominant workplace noise levels emitted by different machines and some machines produce noise levels as high as $100 \mathrm{~dB}$ or more. Among the defined etiologies of hearing loss, noise is the greatest causative factor. Prevention of noise-induced hearing loss (NIHL) has been addressed by providing wearable hearing protection and noise emission reduction [1]. Especially when noise levels exceed 120-140 decibels

Tirtharaj Sen is an Assistant Professor in the Department of Electrical Engineering, Asansol Engineering College, Kanyapur, Vivekananda Sarani, Asansol, Burdwan-713305, India. He was an Ex Assistant Professor \& Head, Dept. of E.E, Bengal Institute of Technology and Management. He has twelve years Industrial experience and nearly six years teaching experience.

(Phone: +91-9432851324, email: tirtha.bitm@gmail.com)

Pijush Kanti Bhattacharjee is an Assistant Professor in the Department of Electronics and Telecommunications Engineering, in Assam University (Central University), Silchar, Assam, India. He was an Ex Asssitant Director in Department of Telecommunications (DoT), Government of India, India. He has possessed vast working experience in the field of Telecommunications including Mobile Communications, VLSI, Management etc. during last 30 years.

(phone: +91-33-25954148, email: pijushbhatta_6@hotmail.com).

Dr. Debamalya Banerjee, Ph.D(Engg.) is currently a Reader in the Department of Production Engg. which is a centre of Advanced study in Jadavpur University. He was a visiting scientist in LfE[Lehrstuhl für Ergonomie], TUM[Technical University of Munich].

(Phone: +91-9432283650, email: debamalya_banerjee@yahoo.co.uk

Dr. Bijan Sarkar is currently a Professor in the Department of Production Engineering which is a centre of Advanced study in Jadavpur University, Kolkata, India.
(dB), for many occupations, this has been effective impact on environmental pollution.

In order to consider both noise level and exposure, noise dose may be defined as the SPL (Sound pressure Level) by which a person may be subjected to a working day of 8 hours; before he runs a permanent hearing loss significantly. The Occupational Safety and Health Administration (OSHA) allow a dose of $90 \mathrm{dBA}$ and are referred to as the noise dose criterion (e.g. 100 percent) level. 100 percent noise dose will represent always the criterion dose, whatever may be the duration of measurement.

The legislation describe on OSHA (1992 A.D.) is that, when a human is exposed to $90 \mathrm{dBA}$ for $8 \mathrm{hrs}$, he has a 100 percent dose. Occupational hearing loss has been studied many researchers (Morihara et. al. 2004, Stansfeld et. al. 2009, Arenas et. al. in 2008), so in the case of those workers who are exposed to 100 percent dose in their workshop floor; the governing noise source of different machines have to be found or checked on regular basis.

\section{Methodology OF THE StUdy}

For studying the characteristics of noise dose at different machines, (Power press) in a small scale industry named 'Arvind Engineers" which is situated at Taratala Road, in Kolkata, West Bengal, India.

The factory unit is a manufacturer of emergency car brake in which different sheet metal components are assembled. For this purpose different power press machines of different capacity $(25 \mathrm{~T}, 10 \mathrm{~T}$, and $150 \mathrm{~T})$ are used. The workers are working in the shop floor nearly $8 \mathrm{hrs}$ to $10 \mathrm{hrs}$ without any hear protection device. We take all noise related reading for $8 \mathrm{hrs}$ by connecting the mouthpiece in workers collar (approx. $10 \mathrm{~cm}$ from the ear ) particularly in summer season from April to June in 2010 A.D. Time Weighted soundpressure level (TWA) criterion level, threshold levels are also calculated. A history of discomfort at the time of production, regarding noise pollution, if any, experienced while the workers are working in front of the press machines is obtained through questionnaire to different individuals in different regions of the shop floors.

\section{A. Instrument Used}

Type 4444, Noise Dose Meter has been used for recording assessment and noise level associated with the workers in that small scale industry is a light weight instrument. There are seven build in setups, which include, ISO 90A, ISO 85A, DOD, MSHA, ACGIH, (USA standards) and obviously a very important unit OSHA, which corresponds to most widely used standards today. The meter 
has a capability to store the data to memory, the sound level setups are specified in which SLM gives on screen result and METER can store data to memory.

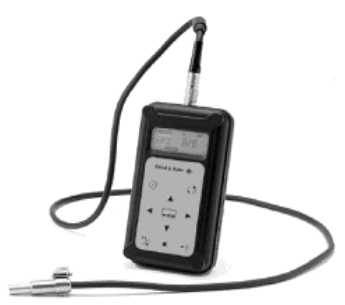

Fig.1.Noise Dose Meter 4444 used for this study

\section{B. Method of measurement}

The manufacturing section of the plant has six $100 \mathrm{~T}$, one $150 \mathrm{~T}$, one $25 \mathrm{~T}$ power press machines and one Grinding machine. All data's are taken during summer, from individual machine for duration of $8 \mathrm{hrs}$. Comparative studies were made for $\mathrm{L}_{\mathrm{eq}}, \mathrm{L}_{\mathrm{av}}, \mathrm{L}_{\mathrm{AE}}$ and TWA (Time weighted average) for different press machines.

Table-1 shows $\mathrm{L}_{\mathrm{eq}}, \mathrm{L}_{\mathrm{av}}, \mathrm{L}_{\mathrm{AE}}$ and TWA for different press machines which are taken directly from meter.

\begin{tabular}{|c|c|c|c|c|}
\hline $\begin{array}{c}\text { Sound level \& } \\
\text { Machine } \\
\text { Type }\end{array}$ & $\mathrm{L}_{\mathrm{eq}}$ & $\mathrm{L}_{\mathrm{AE}}$ & $\mathrm{L}_{\mathrm{av}}$ & TWA \\
\hline $\begin{array}{c}\text { Power press-1 } \\
(100 \text { Ton) }\end{array}$ & 98.0 & 127.0 & 97.7 & 71.9 \\
\hline $\begin{array}{c}\text { Power press-2 } \\
(100 \text { Ton) }\end{array}$ & 96.2 & 125.2 & 95.9 & 70.0 \\
\hline $\begin{array}{c}\text { Power press-3 } \\
(100 \text { Ton) }\end{array}$ & 98.0 & 117.5 & 97.2 & 55.5 \\
\hline $\begin{array}{c}\text { Power press-4 } \\
(100 \text { Ton) }\end{array}$ & 100.6 & 128.7 & 100.3 & 72.9 \\
\hline $\begin{array}{c}\text { Power press-5 } \\
(100 \text { Ton) }\end{array}$ & 111.5 & 126.5 & 108.5 & 59.4 \\
\hline $\begin{array}{c}\text { Power press-6 } \\
(100 \text { Ton) }\end{array}$ & 99.9 & 120.6 & 97.6 & 57.9 \\
\hline $\begin{array}{c}\text { Power press-7 } \\
(100 \text { Ton) }\end{array}$ & 98.2 & 128.0 & 98.0 & 73.4 \\
\hline $\begin{array}{c}\text { Power press } \\
(25 \text { Ton) }\end{array}$ & 98.5 & 128.1 & 98.5 & 73.5 \\
\hline Grinding Machine & 91.6 & 117.1 & 91.5 & 59.8 \\
\hline
\end{tabular}

Where $\mathrm{L}_{\mathrm{eq}}=$ Equivalent sound level,

$\mathrm{L}_{\mathrm{AE}}=$ Sound exposure level,

$\mathrm{L}_{\mathrm{av}}=$ Average sound level,

TWA $=$ Time weighted average.

Table -2 shows Exceedance times for different machines (from SPL level) and $70 \mathrm{~dB}$ to $140 \mathrm{~dB}$ for percentage of run.
TABLE- 2:

\begin{tabular}{|c|c|c|c|c|c|c|}
\hline $\begin{array}{c}\text { Exceedance } \\
\text { Times \& }\end{array}$ & $\begin{array}{c}\text { Above } \\
\text { or } \\
\text { equal } \\
\text { to } 70 \\
\mathrm{~dB}\end{array}$ & $\begin{array}{c}\text { Above } \\
\text { or } \\
\text { equal } \\
\text { to } 85 \\
\mathrm{~dB}\end{array}$ & $\begin{array}{c}\text { Above } \\
\text { or } \\
\text { equal } \\
\text { to } 90 \\
\mathrm{~dB}\end{array}$ & $\begin{array}{c}\text { Above } \\
\text { or } \\
\text { equal } \\
\text { to } 100 \\
\mathrm{~dB}\end{array}$ & $\begin{array}{c}\text { Above } \\
\text { or } \\
\text { equal } \\
\text { to } 115 \\
\mathrm{~dB}\end{array}$ & $\begin{array}{c}\text { Above } \\
\text { or } \\
\text { equal } \\
\text { to } 140 \\
\mathrm{~dB}\end{array}$ \\
\hline $\begin{array}{c}\text { Power } \\
\text { press-1 } \\
(100 \text { Ton) }\end{array}$ & $100 \%$ & $100 \%$ & $100 \%$ & $18.49 \%$ & $0.00 \%$ & $0.00 \%$ \\
\hline $\begin{array}{c}\text { Power } \\
\text { press-2 } \\
(100 \text { Ton) }\end{array}$ & $100 \%$ & $100 \%$ & $98.76 \%$ & $42.5 \%$ & $0.00 \%$ & $0.00 \%$ \\
\hline $\begin{array}{c}\text { Power } \\
\text { press-3 } \\
(100 \text { Ton) }\end{array}$ & $100 \%$ & $95.46 \%$ & $68.56 \%$ & $31.25 \%$ & $0.00 \%$ & $0.00 \%$ \\
\hline $\begin{array}{c}\text { Power } \\
\text { press-4 } \\
(100 \text { Ton) }\end{array}$ & $100 \%$ & $100 \%$ & $98.03 \%$ & $62.35 \%$ & $0.00 \%$ & $0.00 \%$ \\
\hline $\begin{array}{c}\text { Power } \\
\text { press-5 } \\
(100 \text { Ton) }\end{array}$ & $97.60 \%$ & $72.35 \%$ & $70.80 \%$ & $54.45 \%$ & $13.45 \%$ & $0.00 \%$ \\
\hline $\begin{array}{c}\text { Power } \\
\text { press-6 } \\
(100 \text { Ton) }\end{array}$ & $100 \%$ & $97.36 \%$ & $83.58 \%$ & $15.73 \%$ & $0.00 \%$ & $0.00 \%$ \\
\hline $\begin{array}{c}\text { Power } \\
\text { press-7 } \\
(100 \text { Ton) }\end{array}$ & $100 \%$ & $100 \%$ & $99.92 \%$ & $21.19 \%$ & $0.00 \%$ & $0.00 \%$ \\
\hline $\begin{array}{c}\text { Power } \\
\text { press- } \\
(25 \text { Ton) }\end{array}$ & $100 \%$ & $100 \%$ & $100 \%$ & $9.65 \%$ & $0.00 \%$ & $0.00 \%$ \\
\hline $\begin{array}{c}\text { Power } \\
\text { press- } \\
(150 \text { Ton) }\end{array}$ & $100 \%$ & $100 \%$ & $82.08 \%$ & $0.00 \%$ & $0.00 \%$ & $0.00 \%$ \\
\hline $\begin{array}{c}\text { Grinding } \\
\text { Machine }\end{array}$ & $11.47 \%$ & $0.00 \%$ & $0.00 \%$ & $0.00 \%$ & $0.00 \%$ & $0.00 \%$ \\
\hline
\end{tabular}

III. RESULTS AND DISCUSSION

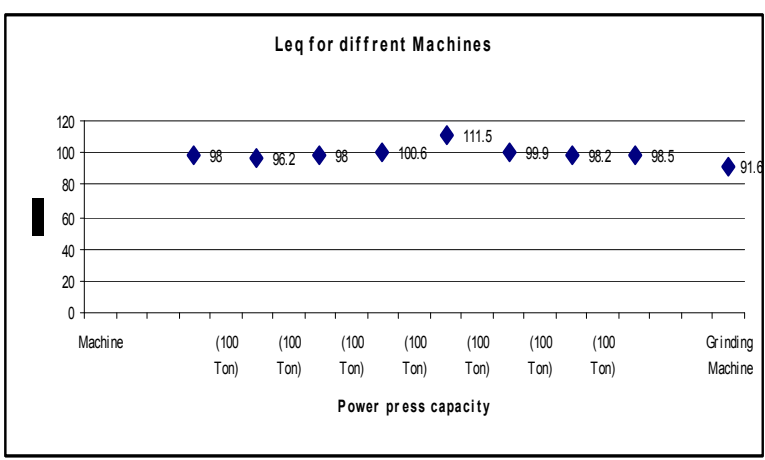

Fig. 2. $\mathrm{L}_{\mathrm{eq}}$ for different machines

LAE for different machines

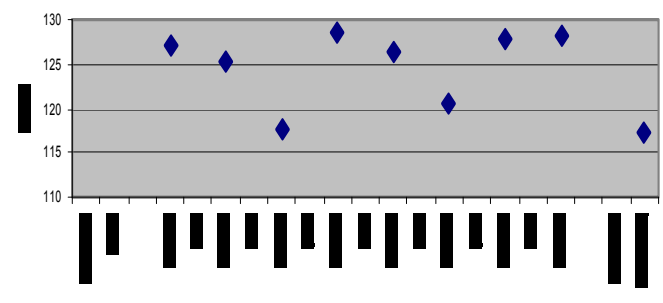

Power press capacity

Fig. 3. $\mathrm{L}_{\mathrm{AE}}$ for different machines 


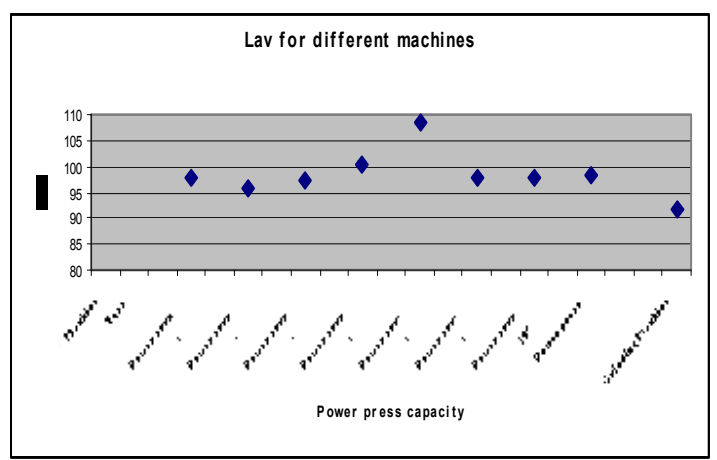

Fig. 4. $\mathrm{L}_{\mathrm{av}}$ for different machine

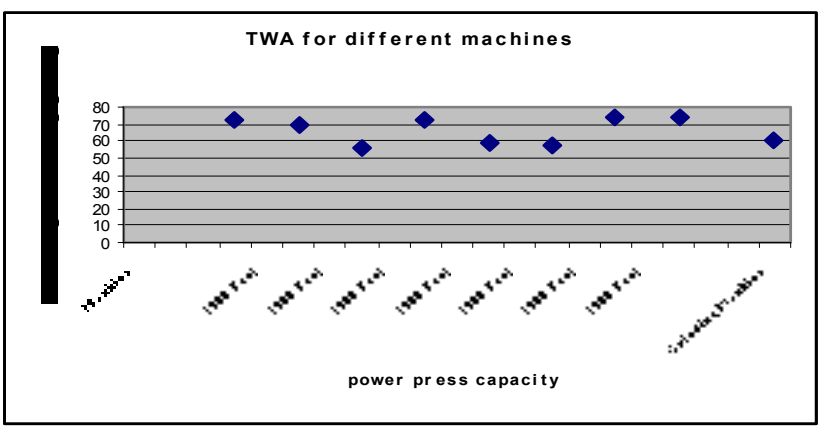

Fig. 5. TWA for different machines

Fig. 2, 3, 4 and 5 shows different noise levels for different machines. Surprisingly it is seen that some lower capacity machines emitted higher sound exposure, e.g., for above or equal to $85 \mathrm{~dB}, 25 \mathrm{~T}$ Power press emitted more noise dose $(100 \%)$ in comparison with high capacity power press. For same capacity machine, (100T) Machine No-4 emitted maximum exceedance time of $62.35 \%$. In the case of above or equal to $115 \mathrm{~dB}$, when all other machines shows $0.00 \%$ exceedance times.

Table-2 clearly indicate that from $70-90 \mathrm{~dB}$, the average exceedance time is $82.199 \%$, as the average exceedance times for above or equal to $70 \mathrm{~dB}$ is $89.90 \%$. For above or equal to $85 \mathrm{~dB}$, it is $86.51 \%$ and for above or equal to $90 \mathrm{~dB}$ it is $70.18 \%$. As far as hearing loss is concerned, average level of exceedance time for $90 \mathrm{~dB}$ is a very dangerous level.

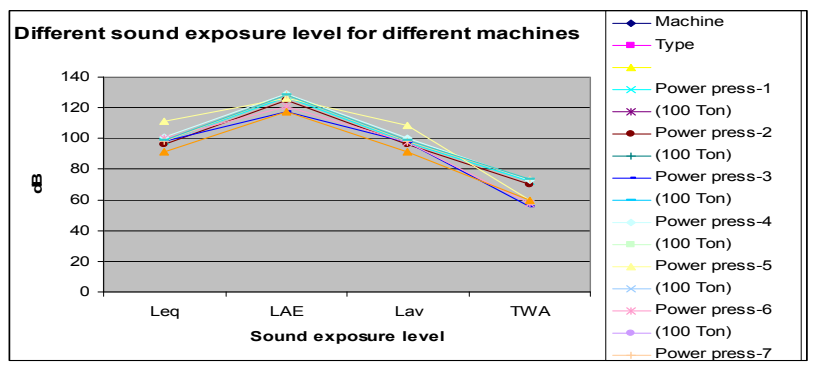

Fig. 6. Different sound exposures for different machines

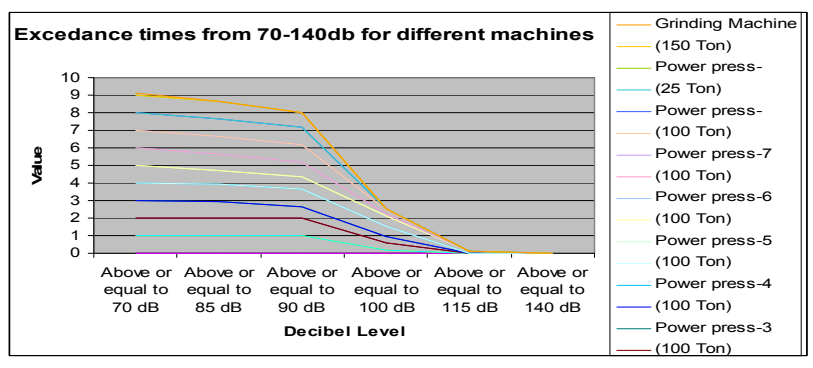

Fig.7. Percentage exceedance times from $70-140 \mathrm{~dB}$ for different machines

Fig. 6 and Fig. 7 show different sound exposure level and percentage exceedance times for different category of machines.

\section{CONCLUSIONS}

From personal conversations with individual workers, it is found that the workers feel very much pain in their ear and migraine in duty hours as well as after duty hours. Some workers face temporary hearing loss and some workers face permanent hearing loss who are working 5 years to 8 years in this plant. It is also observed that due to lack of proper maintenance in some machines, some low capacity machines emitted more noise than the higher capacity machines. This study suggests that noise induced hearing loss is a great challenge in environmental pollution. This noise exposure and occupational noise exposure both interfere with the safety of worker as well as smooth leading in their personal life. The factory management should provide high quality ear plug and other safety devices to each individual worker and surrounding persons to safe guard from this noise exposure. Preventive maintenance should be carried out periodically for frictional portions of all power press machines and other allied parts.

\section{REFERENCES}

[1] Bru“ el, Kjær, 1998a. Technical Documentation-Sound Calibrator $B K 4231$. Bru“" el and Kjær, Naerum, Denmark.

[2] Bru“ el, Kjær, 1998b. Technical Documentation-Integrating and Logging Sound level meterBK 2238 and BK 2260. Bru“ el and Kjær, Naerum, Denmark.

[3] Griefahn B., Marks A., Robens S. " Noise emitted road road, rail, and air traffic and their effects on sleep", Journal of Sound and Vibration, 295(2006) 129-140.

[4] Tirtharaj Sen, Dr. Debamalya Banerjee, Prof. Bijon Sarkar "Exposure of Auto drivers to NoiseDose, in Running Condition in the Kolkata City of West Bengal State"- HWWE 2009, Calcutta University, Kolkata.

[5] T. Sen,,P.K Bhattacharjee, D. Banerjee, B. Sarkar, "Running condition noise dose to auto drivers in kolkata meripolitan city of India in different seasons" International Journal of Environmental Science and Development, vol-I, no-3, pp 278-281, August 2010, ISSN No-2010-0264.

[6] Eric .D. Lynch, J. Kil," Compounds for the prevention and treatment of noise-induced hearin loss" DDT, Vol-10,No-19, October 2005.

[7] S. Mum, Z.W Geem, "Determination of individual sound power levels of noise sources using a harmony such algoroth" International Journal of Indusrial Ergonomics,39(2009), 366-370.

[8] S. A Stansfeld, C. Clark, M.M Haines et al "Aircraft and traffic noise exposure and children's mental health." Journal of EP, 29(2009) 203207.

[9] Chucri. A. Kardous et al "Noise Dosimeter for monitoring exposure to impulse noise", Applied Acoustics, 66(2005), 974-985.

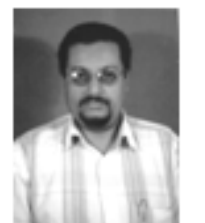

Mr. Tirtharaj Sen is an Assistant Professor in the Department of Electrical Engineering, Asansol Engineering College, Kanyapur, Vivekananda Sarani, Asansol, Burdwan-713305, India. He obtained his B.E (Electrical), M-Tech(Electrical Power) both from Calcutta University and pursuing $\mathrm{PhD}$ at Jadavpur University. He has twelve years Industrial experience in Hindustan Motors Limited(1989-2001). He was an Ex Assistant Professor \& Head, Dept. of E.E, Bengal Institute of Technology and Management, Santiniketan. (2005-2010). He has a number of publications [Both in Journals \& in Proceedings of Conferences, National \& International]. He is a member of Institution of Engineers (India) and IEEE. His research interests are in Noise Pollution, Harmonics and Non Conventional Energy. 


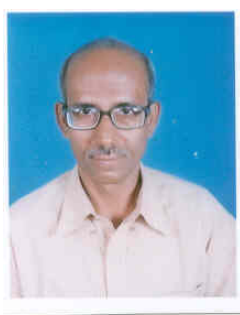

Mr. Pijush Kanti Bhattacharjee is associated with the study in Engineering, Management, Law, Indo-Allopathy, Herbal, Homeopathic \& Yogic medicines. He is having qualifications ME, MBA, MDCTech, AMIE (BE or BTech), BSc(D), BIASM, CMS, PET, EDT, FWT, DATHRY, B.A LLB, KOVID, DH, ACE, FDCI etc. He has started service in Government of India, Department of Telecommunications (DoT) since 1981 as an Engineer, where he has worked upto January, 2007, lastly holding Assistant Director post at Telecom Engineering Centre, DoT, Kolkata, India. Thereafter, he worked at IMPS College of Engineering and Technology, Malda, WB, INDIA as an Assistant Professor in the Department of Electronics and Communication Engineering from January, 2007 to Feb, 2008, from Feb 2008 to Dec, 2008 at Haldia Institute of Technology, Haldia, WB, India, from Dec, 2008 to June, 2010 at Bengal Institute of Technology and Management, Santiniketan, WB, India and June 2010 to Aug, 2010 at Camellia Institute of Technology, Kolkata, India. He joined in Assam University (Central University), Silchar, Assam, India in Sept, 2010 at the same post and department. He has written two books "Telecommunication India" \& "Computer". He is a member of IACSIT, Singapore; CSTA, USA IAENG, Hongkong; and IE, ISTE, IAPQR, IIM, India. His research interests are in Mobile Communications, Image Processing, VLSI, Nanotechnology, Management and Environmental Pollution etc.

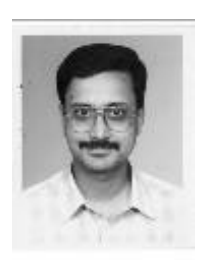

Dr. Debamalya Banerjee, Ph.D(Engg.) is currently a Reader in the Department of Production Engg. which is a centre of Advanced study in Jadavpur University, which has been rated a "Five Star University"[Highest accreditation],by NAAC[National Assessment and Accreditation Council] the official Accreditation Agency of U.G.C of Govt. of India. He has in his credit a number of publications[Both in Journals \& in Proceedings of Conferences, National \& International].He was a visiting scientist in LfE[Lehrstuhl fur Ergonomie],TUM[Technical University of Munich],

Germany and currently looks after all the Ergonomics related activities of the Department, as well as, the University. He has successfully conducted projects on Ergonomics and is currently a Life Member of Indian Society of Ergonomics (ISE), which is federated to the IEA [International Ergonomics Association].

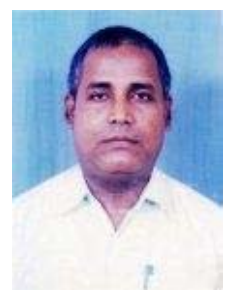

Dr. Bijan Sarkar did his Bachelor and Master of Production Engg. From Jadavpur University, Calcutta, India. Dr. Sarkar has done Doctor of Philosophy $(\mathrm{PhD})$ also from Jadavpur University. He has 15 years of Experioence in the field of teaching, consultancy and research. Dr. Sarkar has published more than 114 papers in National/International conferences and Journals and got the award of Bharat Gaurav. Presently Dr. Sarkar is Professor of Production Engg. Dept. Jadavpur University, Kolkata. His field of interest includes of Al Techniques in Mechanical, Production Management, Tribology. He is a Life Member of Institution of Engineers(India), Indian Society of Technical Education, Society of Reliability Engineers. 